\title{
Chemical Evidence for Cell Wall Lignification and the Evolution of Tracheids in Early Devonian Plants
}

\section{Citation}

Boyce, C. Kevin, George D. Cody, Marilyn L. Fogel, Robert M. Hazen, Conel M. O. Alexander, and Andrew H. Knoll. 2003. Chemical evidence for cell wall lignification and the evolution of tracheids in early Devonian plants. International Journal of Plant Sciences 164(5): 691-702.

\section{Published Version}

http://dx.doi.org/10.1086/377113

\section{Permanent link}

http://nrs.harvard.edu/urn-3:HUL.InstRepos:3196097

\section{Terms of Use}

This article was downloaded from Harvard University's DASH repository, and is made available under the terms and conditions applicable to Other Posted Material, as set forth at http:// nrs.harvard.edu/urn-3:HUL.InstRepos:dash.current.terms-of-use\#LAA

\section{Share Your Story}

The Harvard community has made this article openly available.

Please share how this access benefits you. Submit a story.

\section{Accessibility}


Int. J. Plant Sci. 164(5):691-702. 2003.

(c) 2003 by The University of Chicago. All rights reserved.

$1058-5893 / 2003 / 16405-0003 \$ 15.00$

\title{
CHEMICAL EVIDENCE FOR CELL WALL LIGNIFICATION AND THE EVOLUTION OF TRACHEIDS IN EARLY DEVONIAN PLANTS
}

\author{
C. Kevin Boyce, ${ }^{1, *}$ George D. Cody,, Marilyn L. Fogel, + Robert M. Hazen,, \\ Conel M. O'D. Alexander, $\neq$ and Andrew H. Knoll*
}

\begin{abstract}
*Department of Organismic and Evolutionary Biology, Harvard University, 26 Oxford Street, Cambridge, Massachusetts 02138, U.S.A.; tGeophysical Laboratory, Carnegie Institution of Washington, 5251 Broad Branch Road NW, Washington, D.C. 20015, U.S.A.; and ‡Department of Terrestrial Magnetism, Carnegie Institution of Washington, 5241 Broad Branch Road NW, Washington, D.C. 20015, U.S.A.
\end{abstract}

Anatomically preserved land plant fossils from the Lower Devonian Rhynie Chert contain conducting tissues with cells that range from dark-colored, elongated cells without secondary wall thickenings to tracheids similar to those of extant tracheophytes. A suite of tissue-specific microanalytical techniques was used to assess lignification in fossils of Aglaophyton, Rhynia, and Asteroxylon. Isotope ratio mass spectrometry provides millimeter-scale resolution of carbon isotopic abundances, whereas soft X-ray carbon $(1 s)$ spectromicroscopy provides micrometer-scale resolution of the preservation of organic molecular functionality. The isotopic and organic chemistry of Rhynie Chert plants indicates that the earliest vascular thickenings were probably unlignified and that cell wall lignification may have first appeared in the outer cortex. Only in more derived plants, it seems, was lignin deposited in conducting cells to produce the true tracheids seen today in vascular plants.

Keywords: xylem, tracheid, lignin, Rhynie Chert, paleobotany.

\section{Introduction}

Recently developed techniques of chemical microanalysis (Hemsley et al. 1996; Edwards et al. 1997; House et al. 2000; Boyce et al. 2001, 2002; Kudryavstev et al. 2001) make possible the paleontological study of ancient biochemistries at the cellular or tissue scale. Here we apply microanalytical methods to resolve the distribution of distinctive molecular and isotopic characteristics among tissues in three key early land plants from the Lower Devonian (Pragian) Rhynie Chert of Scotland. At Rhynie, siliceous spring deposits (Kidston and Lang 1921; Trewin 1994; Rice et al. 1995) have preserved-sometimes in life position and commonly with organic cell wall remnants and little compaction or deformation-a range of land plants that span the evolution of tracheids (Kidston and Lang 1917, 1920a, 1920b; Edwards 1993; Remy et al. 1993, 1994; Kenrick and Crane 1997). Our chemical analyses, thus, help to resolve the timing of the chemical and morphological innovations that collectively revolutionized water conduction in early land plants.

As defined in living plants, tracheids are elongated, water conducting cells of the vascular plant sporophyte that are dead at maturity and have cell walls strengthened with secondary thickenings and impregnated with the phenolic polymer lignin (essentially poly-bisphenol). Lignin occurs uniquely in vascular plants where it is embedded in the polysaccharide-based cell

\footnotetext{
${ }^{1}$ Current address: Department of Geophysical Sciences, University of Chicago, 5734 South Ellis Avenue, Chicago, Illinois 60637, U.S.A.; e-mail ckboyce@uchicago.edu.
}

Manuscript received October 2002; revised manuscript received April 2003. walls of some cell types. Detailed investigations of fossils from the Lower Devonian (fig. 1) have demonstrated that many of these cellular characteristics, all consistently associated with tracheids in living plants, accumulated sequentially through time. Protracheophyte fossils possess elongated cells that occupy the same central location as xylem in early tracheophyte axes, but the walls of these cells are smooth (Edwards 1986) and closely resemble the walls of water conducting cells in some mosses (Hébant 1977). Fossils of the rhyniophyte lineage, the sister group to the eutracheophyte clade that includes all living vascular plants (Kenrick and Crane 1997), possess tracheids with unusual S-type wall thickenings distinct from those seen in living plants (Kenrick et al. 1991a; Edwards 1993). Even the restriction of tracheids to the sporophyte generation is an independent characteristic that was one of the latest in the tracheid suite to evolve: the gametophyte fossil Sciadophyton contains S-type tracheids (Kenrick et al. 1991b). Lower Devonian eutracheophyte fossils have tracheids similar to those found in many plants today (Kidston and Lang $1920 b)$.

The same range of fossil plants that show sequential structural innovations may preserve different stages in the physiological evolution of cell wall chemistry, including both lignin biosynthesis itself and the anatomical deployment of lignin within the plant. The presence of lignin in these fossils has been extensively debated, with reference made both to the taphonomy of cell ultrastructure and to the tracheids of basal extant lineages (Edwards 1993; Kenrick and Crane 1997; Friedman and Cook 2000 and accompanying W. G. Chaloner discussion).

Because the isotopic and organic chemistries of lignin and 


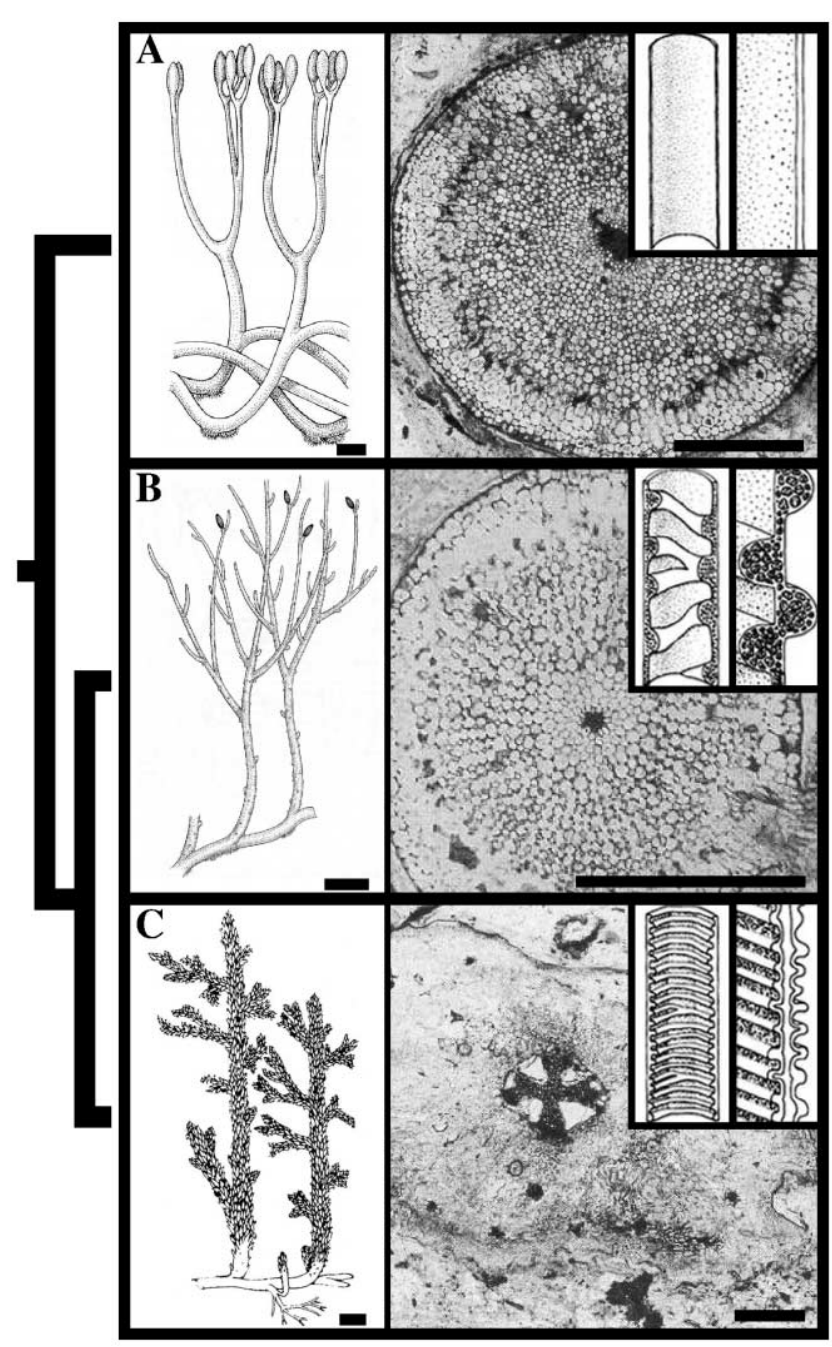

Fig. 1 Evolutionary relationships, reconstructions, stem cross sections, and conducting cell wall anatomy of $(A)$ the protracheophyte Aglaophyton major (images modified from Gensel and Andrews 1984; Kenrick and Crane 1997), (B) the rhyniophyte Rhynia gwynnevaughnii (modified from Kenrick and Crane 1997), and (C) the eutracheophyte Asteroxylon mackiei (modified from Taylor and Taylor 1993; Kenrick and Crane 1997). Scale bars of reconstructions equal $1 \mathrm{~cm}$; scale bars of cross sections equal $1 \mathrm{~mm}$.

cellulose are distinct, chemical analyses may provide a more direct assessment of lignification in early fossil plants than inferences from preserved wall structure. For chemistry to be informative, however, comparative analyses must achieve a high degree of spatial resolution. The carbon isotopic values of lignin are $4 \%-8 \%$ lighter than the cellulose of the same plant (Benner et al. 1987). However, because a host of environmental variables may also affect isotopic values (e.g., Buchmann et al. 1997; Sparks and Ehleringer 1997), lignified and unlignified tissues of the same age within the same fossil plant must be compared in order to distinguish the fractionation due to lignin biosynthesis from that due to environmental fluctuations. Because diagenetic alteration of fossil organic material results in the aromatization of originally nonaromatic material, including cellulose (Boyce et al. 2002), detection of aromatic chemistry in plant fossils is insufficient to indicate the original presence of lignin. One must compare the tissue chemistries of fossils having unambiguously lignified cells with those of fossils bearing tissues of unknown original composition and must do so using specimens that have experienced the same taphonomic history.

Recent taphonomic studies based on fine-scale tissue comparisons verify that the chemistry within fossils is preserved with sufficient spatial resolution to be physiologically informative (Boyce et al. 2001, 2002). Here we employ isotope ratio mass spectrometry on samples drilled manually from fossils (with millimeter-scale spatial resolution) and X-ray spectromicroscopy performed on peels of fossils (with micrometerscale spatial resolution).

\section{Material and Methods}

Organic and isotopic chemical analyses were performed on three genera from the Rhynie Chert representing lineages with distinct gradations of vascular organization: the eutracheophyte Asteroxylon mackiei, the rhyniophyte Rhynia gwynnevaughnii, and the protracheophyte Aglaophyton major. Additional isotopic controls were performed on silicified Araucarioxylon wood from the Lower Carboniferous Olentangy Shale of Ohio and extant, greenhouse-grown Psilotum nudum.

\section{Isotope Ratio Mass Spectrometry}

Samples for isotopic analysis were obtained by drilling the polished surfaces of hand samples containing silica-permineralized plant fossils. Diamond drill bits are preferable for softer cherts, including those preserving Araucarioxylon, but the substantially harder Rhynie Chert requires the use of carbon-free cubic boron nitride bits in order to avoid contamination of the sample with carbon eroded from the drill surface. Drill bits had a $1.2-\mathrm{mm}$ head diameter and produced holes less than $1.5 \mathrm{~mm}$ wide. Drill speeds used were 15,000-18,000 rpm.

The powder resulting from drilling was collected frequently with a steel scalpel and stored in small aluminum foil packets until sufficient powder had been generated for analysis. The powder was then tapped into a tin sample boat. Drill bits, scalpels, and aluminum foil were cleaned before use by sonication for $15 \mathrm{~min}$ in hexane. The delicate sample boats were sonicated in hexane for $1 \mathrm{~min}$, and the fossils were washed with hexane but not sonicated. The surfaces of fossils and all equipment were rinsed with ethanol and allowed to air dry after the collection of each sample. The drill and work area were wrapped in aluminum foil to provide a more dust-free work space that was easier to clean between samples. Sampling of a large quartz crystal following this procedure reveals that no more than $0.5 \mu \mathrm{g}$ of carbon contaminant is introduced during sample preparation (table 1).

Isotopic measurements were made with a Finnigan Delta Plus Excel isotope ratio mass spectrometer with a CE Instruments, NA 2500 series, elemental analyzer and a Conflo II interface. The gas chromatograph oven was set to $60^{\circ} \mathrm{C}$ for the fossil samples. Acetanilide standards were only included at the beginning of each set of analyses (followed by two or 
Table 1

$\delta^{13} \mathrm{C}$ Values for Control Samples of Quartz and Araucarioxylon Wood

\begin{tabular}{|c|c|c|c|c|}
\hline Sample identity & $\begin{array}{l}\text { Sample } \\
\text { size }(\mu \mathrm{g})\end{array}$ & $\begin{array}{l}\text { Voltage } \\
\text { amplitude }\end{array}$ & $\begin{array}{l}\text { Calculated \% } \\
\text { carbon }\end{array}$ & $\delta^{13} \mathrm{C} \%$ \\
\hline \multicolumn{5}{|c|}{$\begin{array}{l}\text { Controls to determine amount of external } \\
\text { carbon contamination: }\end{array}$} \\
\hline Cleaned boat ${ }^{\mathrm{a}}$ & na & No peak & na & na \\
\hline Quartz & 166 & 0.031 & 0.42 & -24.47 \\
\hline Quartz & 72 & No peak & na & na \\
\hline \multicolumn{5}{|c|}{$\begin{array}{l}\text { Araucarioxylon ring samples included in } \\
\text { figures 2, 3: }\end{array}$} \\
\hline Ring 1A & 1132 & 1.598 & 2.66 & -21.00 \\
\hline Ring 1B & 1381 & 2.100 & 2.87 & -21.04 \\
\hline Ring 1C & 2034 & 2.768 & 2.57 & -21.01 \\
\hline Ring 1D & 1805 & 2.434 & 2.55 & -20.95 \\
\hline Ring 1 average & & & & $-21.00 \pm 0.04$ \\
\hline Ring 2A & 1251 & 1.911 & 2.88 & -21.13 \\
\hline Ring 2B & 1536 & 2.365 & 2.92 & -21.03 \\
\hline Ring 2C & 1221 & 1.823 & 2.83 & -21.04 \\
\hline Ring 2D & 1710 & 2.569 & 2.84 & -20.87 \\
\hline Ring 2 average & & & & $-21.02 \pm 0.11$ \\
\hline Ring 3A & 824 & 1.209 & 2.77 & -20.85 \\
\hline Ring 3B & 852 & 1.226 & 2.72 & -20.70 \\
\hline Ring 3C & 1709 & 2.432 & 2.68 & -20.51 \\
\hline Ring 3D & 1174 & 1.645 & 2.64 & -20.53 \\
\hline Ring 3E & 1887 & 2.576 & 2.84 & -20.65 \\
\hline Ring 3 average & & & & $-20.65 \pm 0.14$ \\
\hline \multicolumn{5}{|c|}{$\begin{array}{l}\text { Subsampling of a single Araucarioxylon } \\
\text { sample included in figure 3: }\end{array}$} \\
\hline Subsample 1 & 83 & 0.111 & 3.07 & -21.84 \\
\hline Subsample 2 & 219 & 0.262 & 2.78 & -21.5 \\
\hline Subsample 3 & 36 & 0.079 & 5.08 & -23.7 \\
\hline Subsample 4 & 138 & 0.181 & 3.00 & -20.62 \\
\hline Subsample 6 & 24 & 0.187 & 17.99 & -19.85 \\
\hline Subsample 7 & 44 & 0.076 & 3.95 & -21.68 \\
\hline Subsample 8 & 19 & 0.039 & 4.71 & -22.26 \\
\hline Subsample 9 & 288 & 0.333 & 2.66 & -21.37 \\
\hline Subsample 10 & 109 & 0.144 & 3.08 & -21.43 \\
\hline Subsample 11 & 157 & 0.186 & 2.75 & -21.33 \\
\hline Subsample 12 & 187 & 0.213 & 2.65 & -20.95 \\
\hline Subsample 13 & 619 & 0.652 & 2.47 & -21.02 \\
\hline Subsample 14 & 344 & 0.400 & 2.72 & -20.9 \\
\hline Subsample average & & & & $-21.42 \pm 0.91$ \\
\hline \multicolumn{5}{|c|}{$\begin{array}{l}\text { Additional Araucarioxylon samples included } \\
\text { in figure 3: }\end{array}$} \\
\hline 1 & 102 & 0.159 & 2.85 & -21.32 \\
\hline 2 & 634 & 0.922 & 2.67 & -20.87 \\
\hline 3 & 538 & 0.828 & 2.83 & -20.24 \\
\hline 4 & 243 & 0.353 & 2.69 & -20.64 \\
\hline 5 & 316 & 0.474 & 2.76 & -20.27 \\
\hline 6 & 676 & 0.954 & 2.59 & -19.98 \\
\hline 7 & 315 & 0.439 & 2.56 & -20.71 \\
\hline 8 & 336 & 0.428 & 2.33 & -20.67 \\
\hline 9 & 328 & 0.560 & 3.13 & -20.79 \\
\hline 10 & 85 & 0.149 & 3.22 & -20.82 \\
\hline 11 & 232 & 0.340 & 2.68 & -21.21 \\
\hline 12 & 190 & 0.311 & 3.00 & -20.46 \\
\hline 13 & 338 & 0.535 & 2.90 & -20.91 \\
\hline 14 & 330 & 0.561 & 3.13 & -20.53 \\
\hline 15 & 442 & 0.747 & 3.11 & -20.35 \\
\hline 16 & 1080 & 1.736 & 2.95 & -20.87 \\
\hline Average & & & & $-20.67 \pm 0.35$ \\
\hline
\end{tabular}

${ }^{a}$ No peak was ever detected with the cleaned blank boats run with all subsequent analyses.

${ }^{\mathrm{b}}$ Quartz sampled with cubic boron nitride and Araucarioxylon with diamond drill bits. 
Table 2

Tissue-Specific $\delta^{13} \mathrm{C}$ Values of Psilotum and Rhynie Chert Fossils

\begin{tabular}{lcccc}
\hline Sample identity & $\begin{array}{c}\text { Sample size } \\
(\mu \mathrm{g})\end{array}$ & $\begin{array}{c}\text { Voltage } \\
\text { amplitude }\end{array}$ & $\begin{array}{c}\text { Calculated } \% \\
\text { carbon }\end{array}$ & $\delta^{13} \mathrm{C} \%$ \\
\hline Samples of extant Psilotum: & & & & \\
Psilotum 1-V & 301 & 3.757 & 48.02 & -25.51 \\
Psilotum 1-I & 330 & 3.22 & 37.5 & -24.92 \\
Psilotum 1-O & 334 & 4.349 & 50.14 & -25.19 \\
Psilotum 2-V & 381 & 4.559 & 46.06 & -25.34 \\
Psilotum 2-I & 310 & 3.199 & 39.68 & -24.96 \\
Psilotum 2-O & 386 & 4.869 & 48.53 & -25.22 \\
Psilotum 3-V & 436 & 5.586 & -25.75 \\
Psilotum 3-I & 304 & 3.323 & 49.68 & -25.03 \\
Psilotum 3-O & 317 & 5.992 & 73.05 & -25.26 \\
Average for vasculature minus inner cortex per stem: $-0.56 \pm 0.17$ & & & \\
Largest samples of Aglaophyton fossils included & & & & \\
in figure 5: & & & 0.56 & -25.42 \\
Aglaophyton 1-V & 886 & 0.215 & 0.32 & -25.61 \\
Aglaophyton 1-IC & 1046 & 0.145 & 0.67 & -26.2 \\
Aglaophyton 1-OC & 931 & 0.278 & 0.37 & -24.79 \\
Aglaophyton 2-V & 1254 & 0.199 & -24.89 \\
Aglaophyton 2-IC & ca. 1000 & 0.066 & -25.69 \\
Aglaophyton 2-OC & 1080 & 0.073 & 0.17 & -22.77 \\
Aglaophyton 3-V & 682 & 0.065 & 0.24 & -22.75 \\
Aglaophyton 3-IC & 906 & 0.147 & 0.42 & -23.36 \\
Aglaophyton 3-OC & 921 & 0.101 & 0.28 &
\end{tabular}

Average for vasculature minus inner cortex per stem: $0.09 \pm 0.11$

Average for outer cortex minus vasculature per stem: $-0.76 \pm 0.16$

Average for outer cortex minus inner cortex per stem: $-0.67 \pm 0.12$

Additional, smaller Aglaophyton samples

included in figure 5:

Aglaophyton 4-V

Aglaophyton 4-IC

751

1216

Aglaophyton 4-OC

697

Aglaophyton 5-V

Aglaophyton 5-IC

Aglaophyton 5-OC

840

Aglaophyton 6-V

Aglaophyton 6-IC

Aglaophyton 6-OC

Aglaophyton 7-V

Aglaophyton 7-IC

Aglaophyton 7-OC

Aglaophyton 8-V

Aglaophyton 8-IC

Aglaophyton 8-OC

705

865

572

720

933

255

334

283

Average for vasculature minus inner cortex per stem: $0.57 \pm 1.95$

Average for outer cortex minus vasculature per stem: $0.02 \pm 1.30$

Average for outer cortex minus inner cortex per stem: $0.59 \pm 1.86$

Samples of Rhynia fossils included in figure 6:

Rbynia 1-V

Rhynia 1-C

886

Rhynia 2-V

Rbynia 2-C

Rhynia 3-V

Rhynia 3-C

Rbynia 4-V

Rhynia 4-C

Rbynia 5-V

Rhynia 5-C

Rbynia 6-V

Rhynia 6-C

Rhynia 7-V

Rhynia 7-C

1004

684

672

1380

1410

1110

891

895

770

632

730

888

934
0.104

0.085

0.066

0.093

0.06

0.067

0.06

0.055

0.1

0.072

0.047

0.057

0.053

0.07

0.036

$\begin{array}{ll}0.39 & -24.15 \\ 0.18 & -24.67 \\ 0.25 & -23.11 \\ 0.28 & -23.44 \\ 0.26 & -27.33 \\ 0.19 & -24.18 \\ 0.26 & -25.46 \\ 0.19 & -24.49 \\ 0.27 & -24.1 \\ 0.56 & -20.37 \\ 0.31 & -19.64 \\ 0.42 & -20.14 \\ 0.13 & -24 \\ 0.49 & -24.15 \\ 0.61 & -25.81\end{array}$

0.153

0.137

0.158

0.105

0.083

0.167

0.105

0.103

0.073

0.105

0.081

0.085

0.077

0.083
$-24.92$

$-24.96$

$-25.75$

25.03

.26

25.42

24.79

24.89

$-22.75$

(2)
24.15

$-24.67$

23.11
-23.44

$-27.33$

$-24.18$

$-25.46$

$-24.1$

$-20.37$

$-20.14$

$-24.15$

$-25.81$

-

(n)




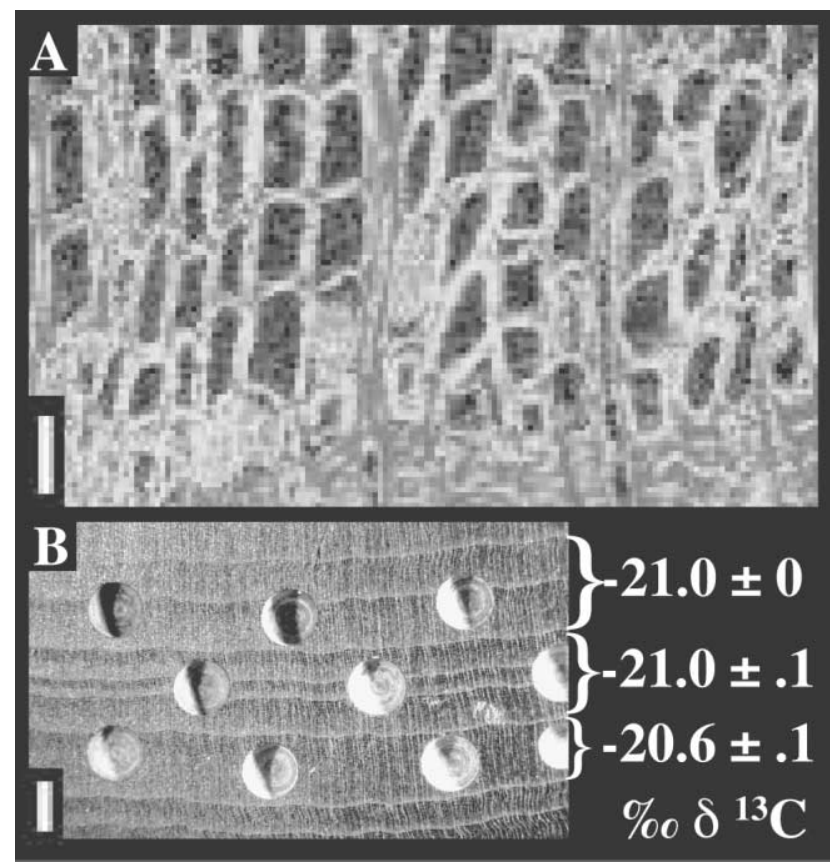

Fig. 2 Petrified Araucarioxylon wood from the Olentangy Shale. $A$, Carbon elemental map with dark indicating low and light indicating high carbon abundance, 50- $\mu$ scale (modified from Boyce et al. 2001). $B$, Sampling and averages of carbon isotopic measurements from successive wood rings. Measurement details found in table 1. Scale bar is $1 \mathrm{~mm}$.

cock 1988; Francis and Hitchcock 1992; Hitchcock et al. 1992), compositional estimates were made using scaled intensities based on published spectra of known compounds (Ishii and Hitchcock 1988; Hitchcock et al. 1992; Ade 1998).

Fossil samples for X-ray spectroscopy must be demineralized and thin enough $(70-200 \mathrm{~nm})$ for X-ray transmission. This thickness was achieved with a minimal loss of spatial resolution by the production of cellulose acetate peels of Rhynie fossil blocks using hydrofluoric acid and following standard procedures (Joy et al. 1956). Peels were embedded in epoxy and sectioned to 100-200 nm perpendicular to the peel surface. This preparation obscures the ultrastructural continuity of individual walls because visualization is in the same plane as the deformation caused by the acetate sheet on organic matter exposed by etching. Despite this deformation, however, the cell type under analysis is still tightly controlled (fig. 7; Boyce et al. 2002). Only the conducting cells of the fossils investigated here have a sufficient density of organic wall material for this technique to be practical. Detailed discussions of sample preparation (Cody 1996; Boyce et al. 2002) and equipment specifications (Jacobsen et. al. 1991) are available elsewhere.

\section{Results}

\section{Isotopic Analyses}

Overall, the carbon isotopic values of the fossils were similar to those of Psilotum. The average of $\delta^{13} \mathrm{C}$ values for Psilotum was $-25.2 \% \pm 0.3 \%$ and for the larger Rhynie Chert samples was $-24.5 \%$ o $\pm 1.0 \%$. $\left(\delta^{13} \mathrm{C}\right.$ values of atmospheric and surface ocean $\mathrm{CO}_{2}$ fluctuated during the Early Devonian, but in general they are estimated to have been ca. $1 \%$ more positive than today; Veizer et al. 1999.) The increased variance for the Rhynie specimens reflects the inclusion of multiple individuals from three different taxa (as opposed to the repeated sampling of a single Psilotum plant). Araucarioxylon samples were also within the range of extant plants that use $\mathrm{C}_{3}$ photosynthesis: mean $\delta^{13} \mathrm{C}$ was $-20.8 \% \pm 0.3 \%$ for samples larger than 100 $\mu \mathrm{g}$.

Within Psilotum, carbon isotopic values of the lignified central vasculature were $0.6 \%$ o $\pm 0.2 \%$ more negative than those of the contemporaneously produced unlignified inner cortex (table 2). As with the fossil Araucarioxylon controls (figs. 2, $3)$, the isotopic measurements from Rhynie fossils are extremely variable in smaller samples but show a decrease in variability with increasing sample size (figs. 5, 6).

Rhynia samples contain little organic matter, and so, despite repeated measurements, isotopic results remained variable and, therefore, physiologically inconclusive across all sample sizes (fig. 6; table 2). In contrast, the larger samples from Aglaophyton produced replicable isotopic ratios. The central conducting strand and inner cortex have approximately equal isotopic values when tissues are compared within cross sections of individual stems. These inner tissues, however, can be differentiated isotopically from the anatomically distinct outer cortex: the outer cortex is $0.7 \%$ o $\pm 0.1 \%$ o more negative (fig. 5; table 2). Asteroxylon shows a different pattern of isotopic heterogeneity; the larger of our few samples show a negative isotopic shift of $0.8 \%$ in the cortex relative to the central xylem (fig. 6B; table 2).

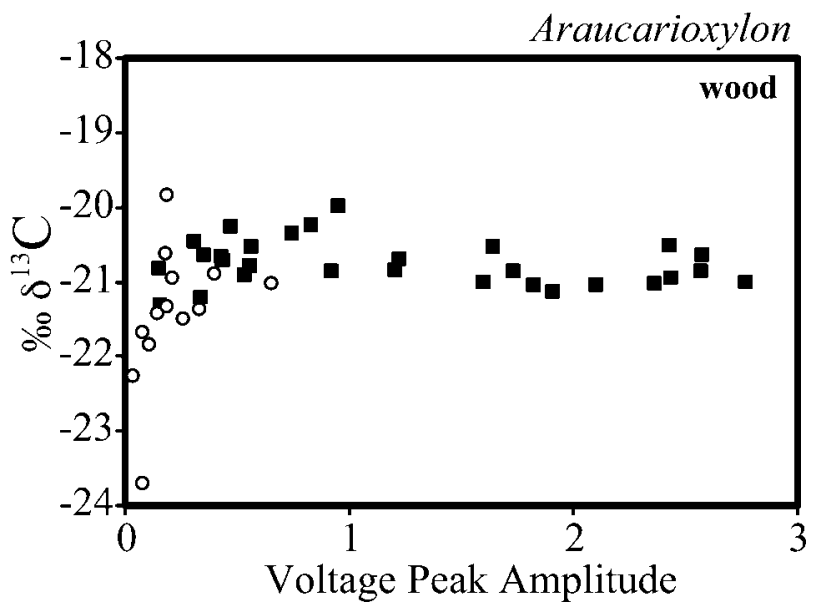

Fig. 3 Carbon isotopic measurements of petrified Araucarioxylon wood from the Olentangy Shale plotted against voltage peak amplitude, which is a measure of sample carbon content as detected by the mass spectrometer. Measurements from a single large homogenous sample being subdivided into 14 samples of varying size (circles). The smallest sample that was attempted was not recognized by the mass spectrometer. Measurement details found in table 1. Subsample measurements plotted against background of all other wood measurements (squares); details found in table 1. 


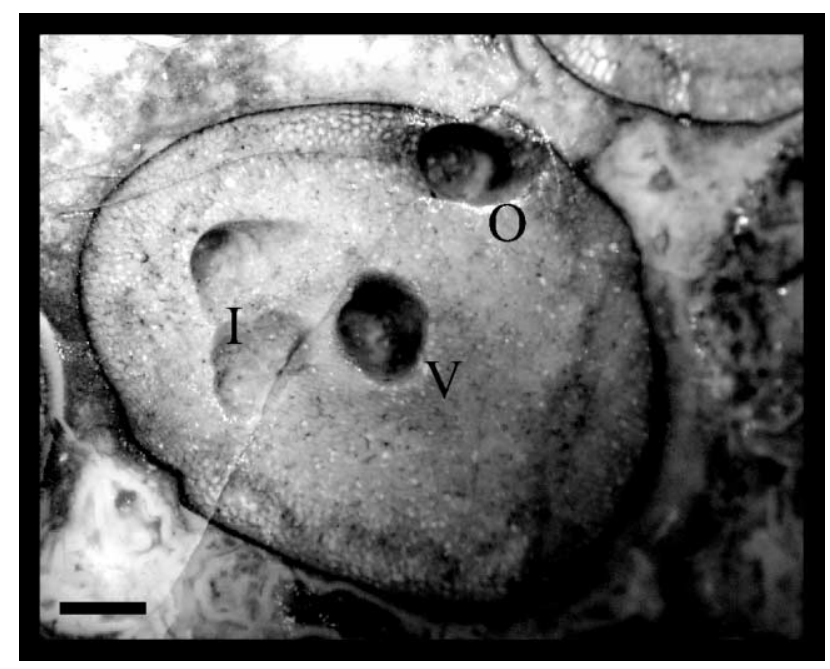

Fig. 4 Example of Aglaophyton stem used for isotopic analysis. Letters indicate drill holes for samples of $(V)$ vasculature, $(I)$ inner cortex, and $(\mathrm{O})$ outer cortex. Only a single type of cortical measurement was made in both Rhynia and Asteroxylon. Scale bar is $1 \mathrm{~mm}$.

\section{Organic Analyses}

As previously documented, Asteroxylon tracheid walls possess two distinct organic zones, similar to the biochemical zonation seen in the tracheids of other fossils and extant plants (Boyce et al. 2002). In contrast, X-ray spectroscopy indicates that the walls of conducting cells in Aglaophyton and Rhynia are more homogenous. Moreover, C-XANES spectra acquired for quantitative organic analysis of the cell walls in the three taxa show that conducting cell walls in Aglaophyton and Rhynia are extremely similar to each other but different from those of Asteroxylon (fig. 8; table 3). Aglaophyton and Rhynia conducting cells retain as much oxygen-bonded aromatic carbon as the tracheid wall layers of Asteroxylon but contain less aromatic carbon overall. Aglaophyton and Rhynia also show greater proportional representation of aliphatic carbon as well as ether and alcohol groups. One of the two wall layers observed in Asteroxylon tracheids reveals a chemical structure reminiscent of those seen in Aglaophyton and Rhynia; it has a similar proportion of single-bonded oxygen groups as well as abundances of aliphatic and aromatic carbon that are intermediate between those of the other Asteroxylon tracheid layer and the conducting cell walls of the other two taxa.

\section{Discussion}

\section{Evidence for Lignification in Rhynie Chert Fossils}

Isotopic comparisons of the lignified xylem protostele and unlignified inner cortex of Psilotum show that lignified tissues are $0.7 \%$ or $0.8 \%$ more negative than unlignified tissues (table 2 ). The full range of isotopic differentiation of $4 \%-8 \%$ between pure lignin and cellulose (Benner et al. 1987) cannot be expected from tissue-scale analyses because lignin exists in vivo only as a lignocellulosic complex. The isotopic analyses of rings in the Lower Carboniferous Araucarioxylon wood indicate that isotopic differences as small as those distinguishing lignified and unlignified tissues can be preserved in fossil plants and can be accurately measured within $\pm 0.1 \%$ (fig. 2 ). However, control studies also indicate that this high degree of isotopic resolution is lost as sample size decreases to below 3-5 $\mu \mathrm{g}$ of carbon (fig. 3). Analyses must, therefore, always be evaluated in terms of sample size, a requirement of particular importance for Rhynie, because preserved fossils are small and have low carbon contents.

Despite the technical limitations on isotopic analyses of Rhynie fossils, Aglaophyton presents a clear and consistent isotopic pattern (table 2). The conducting strand and inner cortex are isotopically indistinguishable. Since the thin-walled parenchyma cells of the inner cortex are probably the least likely in the plant to be lignified, this result suggests that the conducting strand was also unlignified. However, a negative isotopic shift
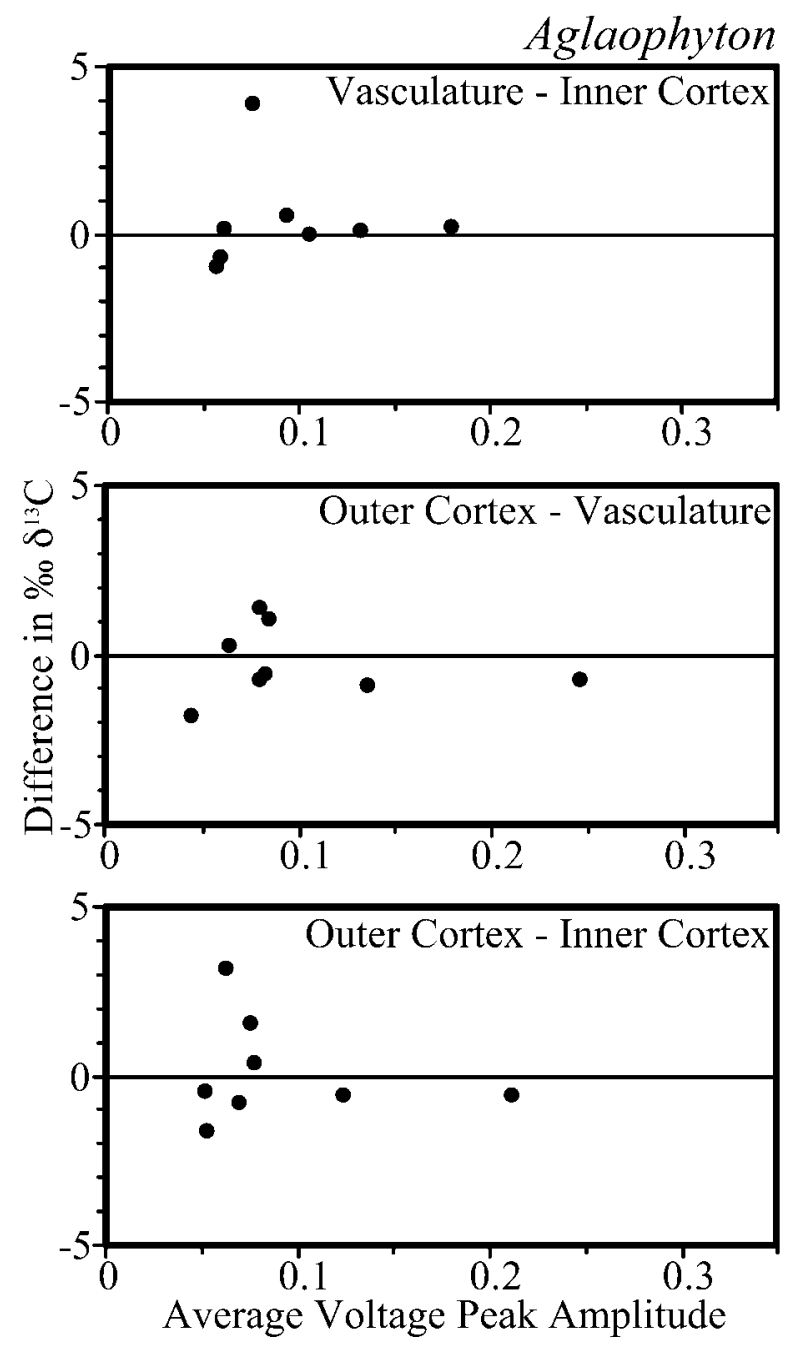

Fig. 5 Comparisons of tissue-specific carbon isotopic values of individual Aglaophyton stems. Each datum represents the carbon isotopic difference between two of the three sampled tissues (vasculature, inner cortex, and outer cortex) from a single stem plotted against the average voltage peak amplitude of the two samples. Details of larger sample measurements included in table 2 , those of smaller samples in table 2 . 


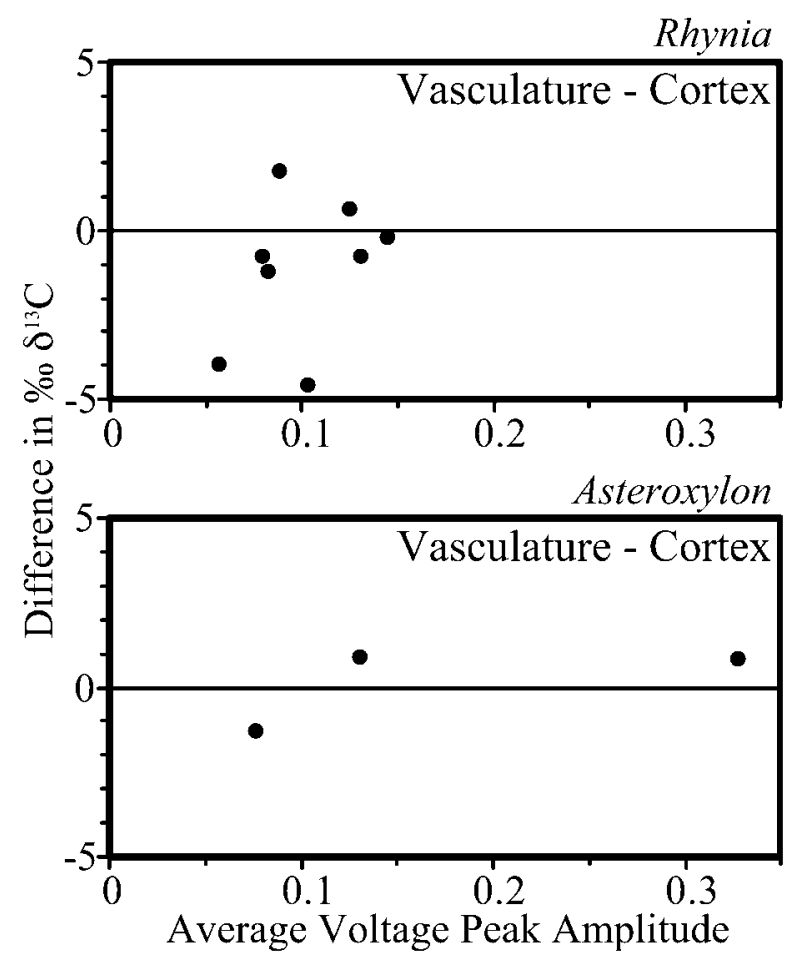

Fig. 6 Comparisons of carbon isotopic values from the vasculature and cortex of individual stems of Rhynia and Asteroxylon. Each datum represents the carbon isotopic difference between the two tissues from a single stem plotted against the average voltage peak amplitude of the two samples. Details of Rhynia measurements included in table 2, those of Asteroxylon samples in table 2.

of the same magnitude as that seen between lignified and unlignified tissues of Psilotum characterizes peripheral tissues of Aglaophyton. This result suggests that Aglaophyton's outer cortex may have been lignified even if the conducting cells were not. Other than lignin, cuticle is the only prominent plant constituent that could both produce this cortical isotopic shift and survive diagenesis. Nuclear magnetic resonance spectroscopy of bulk Rhynie macerates, however, indicates that these plants contained no more aliphatic carbon than would be expected from surficial cuticle (G. D. Cody and C. K. Boyce, unpublished data), which was avoided during isotopic sampling.

The inconclusive isotopic results for Rhynia and Asterox$y$ lon point out an important limitation: tissues can be complexly heterogeneous even at the millimeter scale of sampling. Rhynia possesses a distinct outer cortex similar to that of Aglaophyton, but because Rhynia stems are no more than 3$4 \mathrm{~mm}$ in diameter, only a single cortical measurement was possible. Incorporation of a varying ratio of inner and outer cortex in this single cortical measurement may account for some or all of the isotopic variability that persists in the largest Rhynia samples (fig. 6). If the isotopic variability is indeed caused by imprecise tissue sampling in Rhynia, this would suggest that chemical differentiation between tissues was present.

The cortex of Asteroxylon is even more problematic: lig- nified leaf traces run throughout the cortex, so at this sampling scale, completely unlignified tissues are not available for comparison to the central stele. The aerenchymatous nature of Asteroxylon cortex (Edwards 1993) further complicates microsampling. The few samples available for Asteroxylon suggest that the cortex might be isotopically more negative than the lignified central xylem, perhaps due to isotopic depletions associated with the degradation of the aerenchymatous tissues. Without a finer scale of sampling (e.g., House 2000), however, this difference cannot be resolved.

X-ray spectromicroscopy demonstrates that two distinct organic components contribute to the tracheid cell walls of $A s-$ teroxylon but only a single component is found in the conducting cells of Aglaophyton and Rhynia (fig. 8). The relative
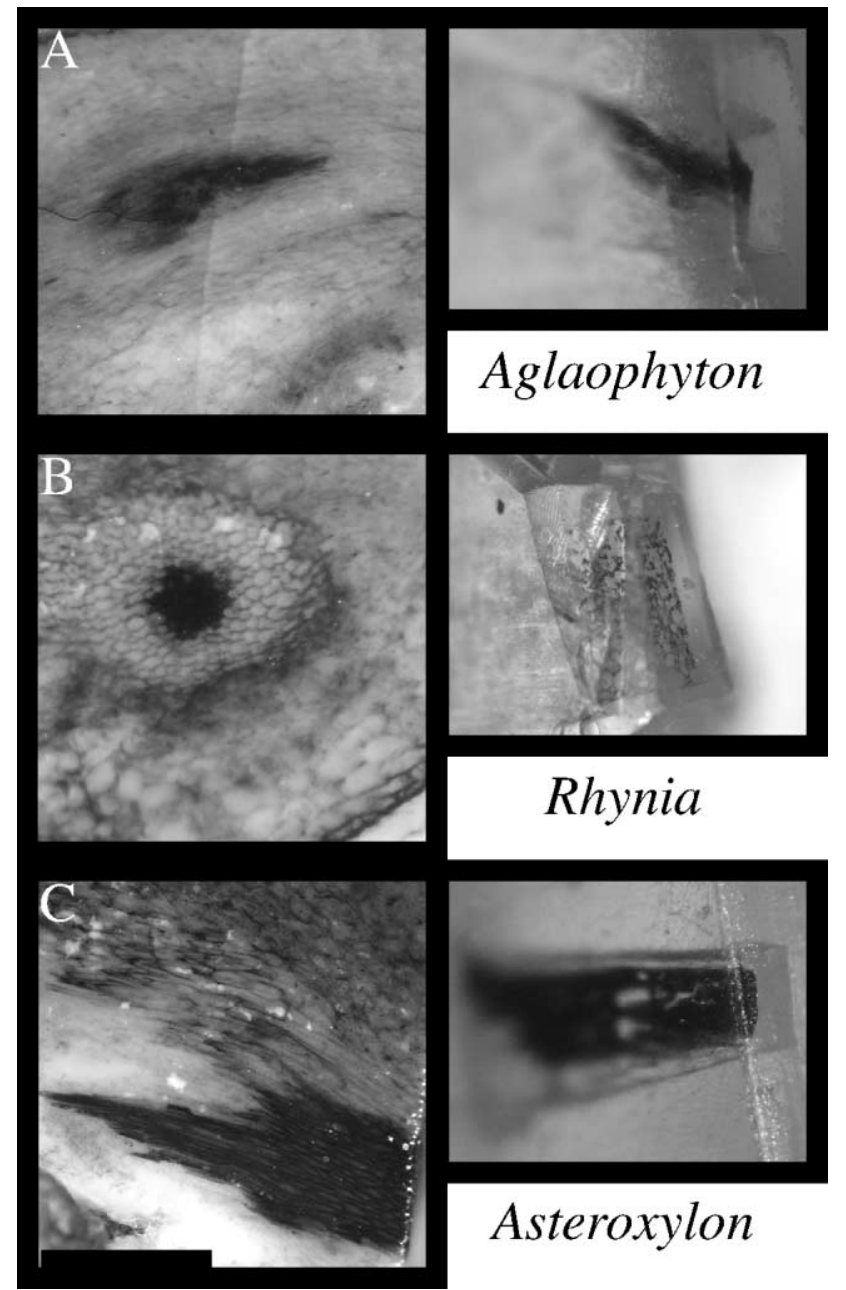

Fig. 7 Xylem analyzed with X-ray spectromicroscopy for $(A)$ Aglaophyton, (B) Rhynia, and (C) Asteroxylon. Images in the left column are of the central vasculature of the fossil stems, and those on the right are of a peel of each fossil embedded in epoxy for X-ray analysis. The microtomed face from which the epoxy-embedded peels were sampled is on the right hand side of each peel image. In each case, only the xylem had sufficient organic matter to be distinguishable in the peel and to permit chemical analysis. Anatomical correlations between fossil and peel images are not exact due to subsequent polishing and sampling of the fossils. Scale bar is $1 \mathrm{~mm}$. 


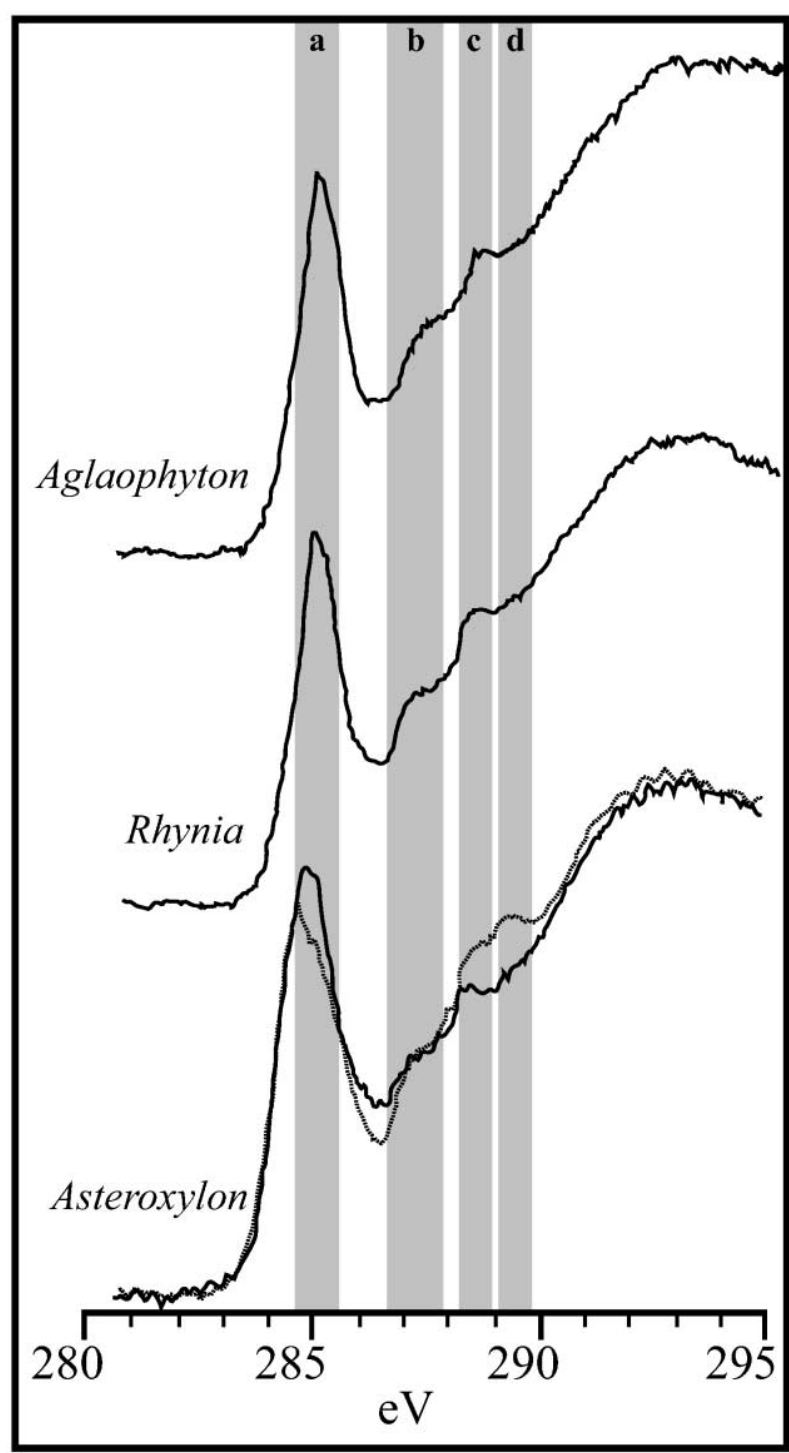

Fig. 8 Stacked plots of carbon near edge X-ray absorption spectra of the vascular cell walls of Rhynie Chert taxa. Two distinct chemistries are found in Asteroxylon, but Rhynia and Aglaophyton share a single chemistry. Columns $a-d$ correspond to absorption frequencies for different types of carbon bonds: $a$, aromatic $\mathrm{C}$; $b$, aromatic $\mathrm{C}-\mathrm{OH} ; c$, $\mathrm{COOH} ; d, \mathrm{COH}$.

broadness of the aromatic $1 s$ to $\pi^{*}$ absorption bands in these spectra is indicative of a broad distribution of variously substituted aromatic molecules, consistent with a high degree of diagenetic alteration. However, the overall similarity of the spectra suggests similar original biochemistries subjected to the same taphonomic history. Because of this diagenetic alteration, $\mathrm{X}$-ray microscopy alone cannot indicate whether the two chemically distinct components correspond to lignified and unlignified walls or lignified walls with different ratios of lignin and cellulose (Boyce et al. 2002). However, since isotopic evidence suggests that lignin was absent from conducting cells of Aglaophyton, observed differences between Asteroxylon and Aglaophyton organic chemistry may indicate that the two vascular organic signals of Asteroxylon represent a wall layer that is relatively heavily lignified and one that is unlignified or at most lightly lignified. Likewise, the close similarities of organic constituents in Aglaophyton and Rhynia, in conjunction with Aglaophyton isotopic data, suggest that the conducting cells of Rhynia were poorly lignified or perhaps even unlignified, despite the presence of tracheids with secondary thickenings. This evidence suggesting that S-type thickenings were poorly lignified provides support for the previous claims (Kenrick and Crane 1991; Kenrick et al. 1991a; Friedman and Cook 2000) that the unusual microstructure of rhyniophyte S-type tracheids results from more extensive degradation than is characteristic of eutracheophyte tracheids.

That said, the chemical evidence presented here is at odds with some taphonomic arguments for the distribution of lignin in Rhynie plants. The dark coloring of protracheophyte and rhyniophyte conducting cells has been taken as prima facie evidence for lignification (Edwards 1993; Kenrick and Crane 1997; Friedman and Cook 2000). The absence of corroborating chemical evidence, however, forces us to entertain the alternative explanation that dark color reflects the abundance rather than the chemical composition of preserved organic matter: dark conducting cells could have had relatively thick, but unlignified, primary walls. However, we cannot rule out the possibility that the differential preservation of conducting cell walls in rhyniophytes and protracheophytes was imparted by phenolic compounds present in amounts too small to influence isotopic composition.

As noted above, microchemical analyses of Rhynie fossils provide evidence that lignification may have originated in the peripheral tissues of protracheophytes and only later been coopted for the strengthening of tracheids in eutracheophytes. This perspective is also supported by anatomical and taphonomic arguments. The presence of partially decayed stems that maintain their cylindrical shape despite the complete loss of the inner tissues (Trewin 1994) is consistent with lignification of the outer cortex (although this feature perhaps does not rule out a lignified conducting strand; degradation of the surrounding inner cortex might be sufficient to disrupt the central strand regardless of wall chemistry). Positive evidence that these conducting cells were not lignified comes from anatomical studies of bryophytes: one of the characteristics of the unlignified, bryophyte water conducting cells is that, when on the periphery of a conducting strand, these dead cells have concave cell walls that respond to the pressure imposed on them by the turgor of adjacent living cells (Hébant 1977). The conducting cells of Aglaophyton and Rhynia show a similar response to the surrounding cells, suggesting their walls were not rigid (e.g., cf. figs. 340, 341 in Hébant 1977).

\section{Evolution of the Tracheid Cell Type}

An initial evolutionary independence of lignification and conducting cell morphology is reasonable on several grounds. First, although many living tracheophytes require lignified $x y-$ lem to support plant mass, the thin central strand of conducting tissue in rhyniophytes would have contributed far less than turgor pressure to axis support (Speck and Vogellehner 1988). Moreover, while the discontinuous rings of secondary 
Table 3

Chemical Structures of Tracheid Cell Wall Derived from C-XANES Spectra

\begin{tabular}{|c|c|c|c|c|c|c|}
\hline \multirow[b]{2}{*}{ Peak } & \multirow[b]{2}{*}{ Transition } & \multirow[b]{2}{*}{$\mathrm{eV}$} & \multicolumn{2}{|c|}{ Asteroxylon } & \multirow[b]{2}{*}{ Rhynia } & \multirow[b]{2}{*}{ Aglaophyton } \\
\hline & & & Layer A & Layer B & & \\
\hline Aromatic carbon $\mathrm{C}_{\mathrm{AR}}-\mathrm{C}, \mathrm{H}$ & $1 s-\pi^{\mathrm{a}}$ & 285.1 & $5.1^{\mathrm{a}}(54 \%)$ & $5.2(49 \%)$ & $5.0(44 \%)$ & $4.9(42 \%)$ \\
\hline Aromatic carbon $\mathrm{C}_{\mathrm{AR}}-\mathrm{O}$ & $1 s-\pi^{\mathrm{a}}$ & 287.2 & $0.9(9 \%)$ & $0.8(7 \%)$ & $1.0(9 \%)$ & $1.1(9 \%)$ \\
\hline Aliphatic carbon $\mathrm{CH}_{1-3}$ & $1 s-\sigma^{\mathrm{ab}}$ & 287.8 & $0.3(3 \%)$ & $0.7(7 \%)$ & $1.1(10 \%)$ & $1.5(13 \%)$ \\
\hline Carboxylate COOR,H & $1 s-\pi^{\mathrm{a}}$ & 288.5 & $0.5(5 \%)$ & $0.5(5 \%)$ & $0.6(5 \%)$ & $0.5(4 \%)$ \\
\hline \multicolumn{7}{|l|}{ Aliphatic ether or alcohol } \\
\hline $\mathrm{C}_{\mathrm{AL}}-\mathrm{O}$ & $1 s-\sigma^{\mathrm{ab}}$ & 289.5 & $2.7(28 \%)$ & $3.5(33 \%)$ & $3.7(32 \%)$ & $3.8(32 \%)$ \\
\hline $\begin{array}{l}\text { No. oxygen atoms per } \\
\text { aromatic ring }\end{array}$ & & & 0.9 & 0.8 & 1.0 & 1.1 \\
\hline
\end{tabular}

${ }^{a}$ Abundances cast in terms of number of carbons normalized to six aromatic carbons (i.e., a single aromatic ring) and in terms of percent of total carbon in parentheses.

${ }^{\mathrm{b}}$ The low energy $1 s-\sigma^{*}$ transitions involve C-H bonding.

wall material in rhyniophytes could have helped prevent cell collapse under the negative pressure of water transport, they could not have supported the axis (reviewed in Bateman et al. 1998). If lignification was involved in the structural support of these fossil axes, it would optimally lie in the stem periphery (Niklas 1997), as is suggested for Aglaophyton.

Raven (1984) proposed that lignin's original function was antimicrobial and that only later did it come to play a structural role in xylem cells. Consistent with this hypothesis, phenolic compounds have been identified in charophyte algae (Delwiche et al. 1988) and bryophytes (Kroken et al. 1996). Raven's proposal implies that lignin in early land plants might have been concentrated along the periphery of axes, and the differential preservation of outer cortex in the Devonian fossil Gosslingia has been adduced as evidence for such a distribution (Kenrick and Edwards 1988). Thus, the evolution of lignified tracheids might have only involved the expression in a different cell type of a preexisting polyphenolic pathway and its targeted cell wall deposition.

The evolution of tracheid wall thickening independent of lignification is also consistent with xylem development in living plants. In the Zinnia model system of tracheid differentiation, patterned lignin deposition is dependent on the prior initiation of cellulose secondary thickenings and is disrupted by inhibitors of cellulose synthesis (reviewed in McCann 1997). This developmental pattern has been confirmed in pteridophytes with tracheid ultrastructure more similar to early fossils (Friedman and Cook 2000).

Mosiac evolution is not uncommon for plants (Knoll et al. 1984). Convergent evolution of form is also widespread (e.g., Boyce and Knoll 2002), and virtually all cell characteristics associated with tracheids have evolved repeatedly among the bryophytes. The prevalence of phenolic wall chemistry in peripheral tissues was mentioned above. Phenolic chemistry is also present in some bryophyte water conducting cells but only within derived polytrichalean mosses (Ligrone et al. 2000).
Cell elongation and anatomical variations in cell wall thickness are found in nearly all taxa. Helical, cellulosic wall thickenings similar to those of Rhynia tracheids occur in the elaters of liverworts and occasionally in hornwort columellae (Hébant 1977). Cell wall pitting is found in a variety of cell types, including conducting cells, in many taxa (Hébant 1977; Ligrone et al. 2000). Programmed cell death as part and parcel of cell function occurs in liverwort elaters, in water conducting cells, and in cortical cells of a variety of groups (Hébant 1977). Auxin gradients established by polar auxin transport are used for the patterning of vascular cell differentiation in tracheophytes (Sachs 1991), and similar gradients have been documented in liverworts (Maravalo 1980). What makes tracheids unique is that this entire suite of chemical, developmental, and morphological traits co-occur in a single cell type shaped by sequential evolutionary events in early land plants.

\section{Acknowledgments}

This research was supported by the NASA Astrobiology Institute, the National Science Foundation (NSF; EAR-MRI 9724317), and the W. M. Keck Foundation. The scanning transmission X-ray microscope at the National Synchrotron Light Source was developed by the group of J. Kirz and C. Jacobsen at State University of New York, Stony Brook, with support from the Office of Biological and Environmental Research of the U.S. Department of Energy (DE-FG0289ER60858) and the NSF (DBI-9605045). This manuscript was greatly improved by comments of two anonymous reviewers. We thank Nigel Trewin for providing Rhynie Chert specimens, Steven Scheckler for identification of the fossil wood, Sue Wirick for technical support with the X-ray microscope, Mark Teece for advice on isotopic analyses, and Matthew Wooller for analytical advice and discussion of the manuscript.

\section{Literature Cited}

Ade H 1998 X-ray spectromicroscopy. Exp Method Phys Sci 32:225262.

Bateman RM, PR Crane, WA DiMichele, PR Kenrick, NP Rowe, T
Speck, WE Stein 1998 Early evolution of land plants: phylogeny, physiology, and ecology of the primary terrestrial radiation. Annu Rev Ecol Syst 29:263-292. 
Benner R, ML Fogel, EK Sprague, RE Hodson 1987 Depletion of ${ }^{13} \mathrm{C}$ in lignin and its implications for stable carbon isotope studies. $\mathrm{Na}-$ ture 329:708-710.

Boyce CK, GD Cody, M Feser, C Jacobsen, AH Knoll, S Wirick 2002 Organic chemical differentiation within fossil plant cell walls detected with X-ray spectromicroscopy. Geology 30:10391042.

Boyce CK, AH Knoll 2002 Evolution of developmental potential and the multiple independent origins of leaves in Paleozoic vascular plants. Paleobiology 28:70-100.

Boyce CK, AH Knoll, RM Hazen 2001 Nondestructive, in situ, cellular-scale mapping of elemental abundances including organic carbon in permineralized fossils. Proc Natl Acad Sci USA 98:59705974.

Buchman N, J-M Guehle, TS Barigah, JR Ehleringer 1997 Interseasonal comparison of $\mathrm{CO}_{2}$ concentrations, isotopic composition, and carbon dynamics in an Amazonian rainforest (French Guiana). Oecologia 110:120-131.

Cody GD, RE Botto, H Ade, S Wirick 1996 The application of soft $\mathrm{X}$-ray microscopy to the in-situ analysis of sporinite in coal. Int J Coal Geol 32:69-86.

Delwiche CF, LE Graham, N Thomson 1989 Lignin-like compounds and sporopollenin in Coleochaete, an algal model for land plant ancestry. Science 245:399-401.

Edwards D 1993 Tansley review no. 53: cells and tissues in the vegetative sporophytes of early land plants. New Phytol 125:225-247.

Edwards D, G Ewbank, GD Abbott 1997 Flash pyrolysis of the outer cortical tissues in Lower Devonian Psilophyton dawsonii. Bot J Linn Soc 124:345-360.

Edwards DS 1986 Aglaophyton major, a non-vascular plant from the Devonian Rhynie Chert. Bot J Linn Soc 93:173-204.

Francis JT, AP Hitchcock 1992 Inner-shell spectroscopy of p-benzoquinone, hydroquinone, and phenol: distinguishing quinoid and benzoid structures. J Phys Chem 96:6598-6610.

Friedman WE, ME Cook 2000 The origin and early evolution of tracheids in vascular plants: integration of palaeobotanical and neobotanical data. Phil Trans R Soc Lond B Biol Sci 355:857-868.

Gensel PG, HN Andrews 1984 Plant life in the Devonian. Praeger, New York.

Hébant C 1977 The conducting tissue of bryophytes. Cramer, Vaduz.

Hemsley AR, AC Scott, PJ Barrie, WG Chaloner 1996 Studies of fossil and modern spore wall biomacromolecules using C-13 solid state NMR. Ann Bot 78:83-94.

Hitchcock AP, SG Urquhart, EG Rightor 1992 Inner-shell spectroscopy of benzaldehyde, terephthalaldehyde, ethyl benzoate, terephthaloyl chloride, and phosgene: models for core excitation of poly(ethylene terephthalate). J Phys Chem 96:8736-8750.

House CH, JW Schopf, KD McKeegan, CD Coath, TM Harrison, KO Stetter 2000 Carbon isotopic composition of individual Precambrian microfossils. Geology 28:707-710.

Ishii I, AP Hitchcock 1988 The oscillator strengths for carbon-1s and oxygen-1s excitation of some saturated and unsaturated organic alcohols, acids and esters. J Electron Spectrosc 46:55-84.

Jacobsen C, S Williams, E Anderson, MT Browne, CJ Buckley, D Kern, J Kirz, M Rivers, X Zhang 1991 Diffraction-limited imaging in a scanning transmission $\mathrm{x}$-ray microscope. Opt Commun 86:351-364.

Joy KW, AJ Willis, WS Lacey 1956 A rapid cellulose peel technique in palaeobotany. Ann Bot 20:635-637.

Kenrick P, PR Crane 1991 Water-conducting cells in early fossil land plants: implications for the early evolution of tracheophytes. Bot Gaz 152:335-356.

1997 The origin and early diversification of land plants. Smithsonian Institution, Washington, D.C.

Kenrick P, D Edwards 1988 The anatomy of Lower Devonian Gosslingia breconensis Heard based on pyritized axes, with some comments on the permineralization process. Bot J Linn Soc 97: 95-123.

Kenrick P, D Edwards, RC Dales 1991 a Novel ultrastructure in waterconducting cells of the Lower Devonian plant Sennicaulis hippocrepiformis. Palaeontology 34:751-766.

Kenrick P, W Remy, PR Crane 1991b The structure of waterconducting cells in the enigmatic early land plants Stockmensella langii Fairon-Demaret, Huvenia kleui Hass et Remy, and Sciadophyton sp. Remy et al. 1980. Argumenta Palaeobot 8:179-191.

Kidston R, WH Lang 1917 On Old Red Sandstone plants showing structure, from the Rhynie Chert Bed, Aberdeenshire. Pt 1. Rhynia Gwynne-Vaughanii, Kidston and Lang. Trans R Soc Edinb 51:761784.

_ 1920a On Old Red Sandstone plants showing structure, from the Rhynie Chert Bed, Aberdeenshire. Pt 2. Additional note on Rhynia Gwynne-Vaughanii, Kidston and Lang; with descriptions of Rhynia major, n.sp., and Hornea Lignieri n.g., n.sp. Trans R Soc Edinb 52:603-627.

— $1920 \mathrm{~b}$ On Old Red Sandstone plants showing structure, from the Rhynie Chert Bed, Aberdeenshire. Pt 3. Asteroxylon mackiei, Kidston and Lang. Trans R Soc Edinb 52:643-680.

__ 1921 On Old Red Sandstone plants showing structure, from the Rhynie Chert Bed, Aberdeenshire. Pt 5. The thallophyta occurring in the peat-bed; the succession of the plants throughout a vertical section of the bed, and the conditions of accumulation and preservation of the deposit. Trans R Soc Edinb 52: 855-902.

Knoll AH, KJ Niklas, PG Gensel, BH Tiffney 1984 Character diversification and patterns of evolution in early vascular plants. Paleobiology 10:34-47.

Kroken SB, LE Graham, ME Cook 1996 Occurrence and evolutionary significance of resistant cell walls in charophytes and bryophytes. Am J Bot 83:1241-1254.

Kudryavtsev A, JW Schopf, DG Agresti, TJ Wdowiak 2001 In situ laser-Raman imagery of Precambrian microscopic fossils. Proc Natl Acad Sci 98:823-826.

Leavitt SW, A Long 1982 Stable carbon isotopes as a potential supplemental tool in dendrochronology. Tree Ring Bull 42:49_ 55 .

Ligrone R, JG Duckett, KS Renzaglia 2000 Conducting tissues and phyletic relationships of bryophytes. Phil Trans R Soc Lond B Biol Sci 355:795-813.

Loader NJ, VR Switsur, EM Field 1995 High resolution stable isotope analysis of tree rings: implications of "microdendroclimatology" for palaeoenvironmental research. Holocene 5:457-460.

Maravolo NC 1980 Control of development in hepatics. Bull Torrey Bot Club 107:308-324.

McCann MC 1997 Tracheary element formation: building up to a dead end. Trends Plant Sci 2:333-338.

Niklas KJ 1997 The evolutionary biology of plants. University of Chicago Press, Chicago.

Raven JA 1984 Physiological correlates of the morphology of early vascular plants. Bot J Linn Soc 88:105-126.

Remy W, PG Gensel, H Hass 1993 The gametophyte generation of some Early Devonian land plants. Int J Plant Sci 154:35-58.

Remy W, TN Taylor, H Hass, H Kerp 1994 Four hundred-millionyear-old vesicular arbuscular mycorrhizae. Proc Natl Acad Sci USA 91:11841-11843.

Rice CM, WA Ashcroft, DJ Batten, AJ Boyce, JBD Caulfield, AE Fallick, MJ Hole, et al 1995 A Devonian auriferous hot spring system, Rhynie, Scotland. J Geol Soc Lond 152:229-250.

Sachs T 1991 Pattern formation in plants. Cambridge University Press, Cambridge.

Sparks JP, JR Ehleringer 1997 Leaf carbon isotope discrimination and nitrogen content for riparian trees along elevational transects. Oecologia 109:362-367. 
Speck TS, D Vogellehner 1988 Biophysical examinations of the bending stability of various stele types and the upright axes of early "vascular" land plants. Bot Acta 101:262-268.

Stöhr J 1992 NEXAFS spectroscopy. Springer, Belin.

Taylor TN, EL Taylor 1993 The biology and evolution of fossil plants. Prentice Hall, Englewood Cliffs, N.J.
Trewin N 1994 Depositional environment and preservation of biota in the Lower Devonian hot-springs of Rhynie, Aberdeenshire, Scotland. Trans R Soc Edinb 84:433-442.

Veizer J, D Ala, K Azmy, P Bruckschen, D Buhl, F Bruhn, GAF Carden, et al $1999{ }^{87} \mathrm{Sr} /{ }^{86} \mathrm{Sr}, \delta^{13} \mathrm{C}$ and $\delta^{18} \mathrm{O}$ evolution of Phanerozoic seawater. Chem Geol 161:59-88. 